\title{
Immunogenetic Therapy of Human Melanoma Utilizing Autologous Tumor Cells Transduced to Secrete Granulocy te-Macrophage Colony-Stimulating Factor
}

\author{
ALFRED E. CHANG,${ }^{1}$ QIAO LI, ${ }^{1}$ D. KEITH BISHOP,${ }^{2}$ DANIEL P. NORMOLLE,${ }^{3}$ BRUCE D. REDMAN,${ }^{4}$ \\ and BRIAN J. NICKOLOFF ${ }^{5}$
}

\begin{abstract}
We performed a clinical study of five patients with melanoma to evaluate the immunobiological effects of retrovirally transduced autologous tumor cells given as a vaccine to prime draining lymph nodes. Patients were inoculated with both wild-type (WT) and GM-CSF gene-transduced tumor cells in different extremities. Approxim ately 7 days later, vaccine-primed lymph nodes (VPLNs) were removed. There was an increased infiltration of dendritic cells (DCs) in the GM-CSF-secreting vaccine sites compared with the WT vaccine sites. This resulted in a greater number of cells harvested from the GM-CSF-VPLNs compared with the WT-VPLNs at a time when serum levels of GM-CSF were not detectable. Four of five patients proceeded to have the adoptive transfer of GM-CSF-VPLN cells secondarily activated and expanded ex vivo with anti-CD3 MAb and IL2. One patient had a durable complete remission of metastatic tumor. Utilizing cytokine (IFN- $\gamma$, GM-CSF, IL-10) release assays, GM-CSF-VPLN T cells manifested diverse responses when exposed to tumor antigen in vitro. In two of two patients, GM-CSF-VPLN T cell responses were different from those of matched WTVPLN cells. This study documents measurable immunobiologic differences of GM-CSF-transduced tumor cells given as a vaccine compared with WT tumor cells. The complete tumor remission in one patient provides a rationale to pursue this approach further.
\end{abstract}

\section{OVERVIEW SUMMARY}

This study was designed to evaluate the adoptive immunotherapy of stage IV melanoma patients with lymph node cells primed by GM-CSF-transduced autologous tumor cells. The intradermal injection of GM-CSF-secreting tumor cells resulted in a greater influx of DCs to the vaccine sites compared with WT tumor vaccines given as a control, as well as an increased number of VPLN cells. Patients were treated intravenously with anti-CD3/IL-2-activated GM-CSF-VPLN cells along with the concomitant administration of IL-2. One of five patients in the study had a complete durable response to treatment. Further studies of this approach are warranted.

\section{INTRODUCTION}

$\mathbf{T}$ He adoptive transfer of sensitized $T$ cells has been demonstrated to mediate the regression of advanced tumors in a variety of animal models (Rosenberg et al., 1986; Chou et al., 1988a). A major obstacle that confronts the clinical application of adoptive immunotherapy is the relatively weak immunogenicity of human cancers, as well as tumor-induced immunosuppression, which hampers the induction of immune effector $\mathrm{T}$ cells. We have concentrated on developing methods to generate and expand immune T cells from either tumor-draining or vaccine-primed lymph nodes (VPLNs) (Chou et al., 1988b; Shu et al., 1989; Yoshizawa et al., 1991; Geiger et al., 1993). These lymph nodes harbor "preeffector" $T$ cells that can

\footnotetext{
${ }^{1}$ Division of Surgical Oncology, University of Michigan, Ann Arbor, MI 48109.

${ }^{2}$ General Surgery Section, University of Michigan, Ann Arbor, MI 48109.

${ }^{3}$ Biostatistics Core, University of Michigan Cancer Center, University of Michigan, Ann Arbor, MI 48109.

${ }^{4}$ Division of Hematology-Oncology, University of Michigan, Ann Arbor, MI 48109.

${ }^{5}$ Department of Pathology, Loyola University, Maywood, IL 60153.
} 
be preferentially activated by a variety of in vitro methods and subsequently transferred back to the tumor-bearing host for therapeutic benefit. We have chosen to prime lymph nodes with autologous tumor cells utilized as a vaccine in conjunction with an immune adjuvant. The use of autologous tumor cells has the advantage of vaccinating the individual with an array of antigens unique for that individual. The focus of this study was to investigate a novel method of delivering an immune adjuvant.

Observations in animal studies have shown that tumor cells can be genetically altered to enhance the host immune response against parental tumor antigens. Various cytokine genes have been evaluated in preclinical models of gene-modified tumor cell vaccinations followed by challenge of parental cells (Fearon et al., 1990; Gansbacher et al., 1990; Asher et al., 1991; Colombo et al., 1991; Golumbek et al., 1991; Dranoff et al., 1993). Granulocyte-m acrophage colony-stimulating factor (GM-CSF) appears to be a superior cytokine as an adjuvant in this setting (Dranoff et al., 1993). GM-CSF is a 23-kDa glycoprotein that was initially shown to promote the in vitro proliferation and differentiation of hematopoietic progenitors to neutrophils and macrophages. Other studies have shown that GM-CSF can also induce the generation of eosinophils, erythrocytes, and megakaryocytes (Donahue et al., 1986; Metcalf et al., 1987). Also, GM-CSF is an important growth factor for dendritic cells (DCs), and essential for the normal function of DCs (Witmar-Pack et al., 1987; Sallusto and Lanzavecchia, 1994). In the setting of tumor-induced immune suppression, GM-CSF can reverse the suppressed function of tumor-derived DCs (Nestle et al., 1997a). DCs are critical in the sensitization of naive $\mathrm{CD}^{+}{ }^{+}$and $\mathrm{CD} 8^{+} \mathrm{T}$ cells to antigen (Fields et al., 1998; Perez-Diez et al., 1998). These properties make GM-CSF an appropriate adjuvant to use in a genetically engineered autologous tumor vaccine.

We designed a clinical trial involving melanoma patients to evaluate the adoptive transfer of activated lymph node cells primed in vivo with autologous tumor cells transduced with the GM-CSF gene. Tumor cells were derived from each patient and placed in bulk culture, during which time they were transduced by a retroviral vector. These cells were utilized as irradiated tumor cell vaccines to prime draining lymph nodes. The VPLN cells were harvested and subsequently activated by an anti-CD3/interleukin 2 (IL-2) culture method we have previously described in a prior clinical study (Chang et al., 1997); and adoptively transferred into patients with the concomitant administration of IL-2. The specific aims of the protocol were to (1) assess the feasibility and toxicity of this treatment, (2) evaluate the in vitro immunological reactivities of the VPLN cells to autologous tumor, and (3) evaluate the antitumor efficacy of the therapy.

\section{MATERIALS AND METHODS}

\section{Treatment plan}

Patients with stage IV melanoma were eligible and required to have a performance status on the Eastern Cooperative Oncology Group (ECOG) scale of 0 or 1. Patients were excluded if brain metastases were detectable by computed tomography (CT) or magnetic resonance imaging (MRI). Other eligibility and exclusion criteria have been published (Chang et al., 1996).
Patients underwent surgical retrieval of tumor to generate the vaccine. Early-passage tumor cells were transduced with a retroviral vector containing the GM-CSF gene. The transduced cells were assayed for GM-CSF production and irradiated with 5000 cGy. Patients were vaccinated with $1-2 \times 10^{7}$ irradiated transduced tumor cells in two separate sites. In several of the patients, wild-type (WT) tumor cells were similarly irradiated and injected as a control vaccine. The control vaccine was placed at a separate site in order to retrieve VPLN from a different nodal basin. Surgical removal of GM-CSF VPLN and WT VPLN occurred 7 to 10 days after vaccination. The cells from the VPLN underwent ex vivo activation with anti-CD3 monoclonal antibody (MAb) and expansion in IL-2. After activation, the lymphocytes were transferred intravenously to the patient followed by the intravenous administration of IL-2 every $8 \mathrm{hr}$ for 15 doses. Patients were monitored for toxicity in the General Clinical Research Center (GCRC) at the University of Michigan (Ann Arbor, MI). After therapy, the patients were assessed for tumor response at 4 and 8 weeks. If there was stable disease or evidence of tumor response, patients were retreated with cells activated from cryopreserved VPLN. Repeat treatments were continued until VPLN cells were no longer available, at which time IL-2 was administered until best response was achieved. This protocol was approved by the University of Michigan Institutional Review Board, National Institutes of Health Recombinant DNA Advisory Committee, and the Food and Drug Administration (FDA).

\section{Retroviral vector: $M F G-G M-C S F$}

MFG-GM-CSF is a Moloney murine leukem ia virus that encodes human GM-CSF and was developed by R. Mulligan (Somatix Therapy, Alameda, CA). Somatix Therapy supplied FDA-approved clinical-grade viral particles used in this study (IND BB5229). In this vector, Moloney murine leukemia virus (Mo-MuLV) long terminal repeat (LTR) sequences are used to generate both a full-length viral RNA necessary for the generation of viral particles and a subgenomic mRNA analogous to the Mo-MuLV env RNA, which is responsible for the expression of human GM-CSF (huGM-CSF. The vector retains both sequences in the viral gag region shown to improve the encapsidation of viral RNA and the normal viral 5' and 3' splice sites necessary for generation of the subgenomic RNA. DNA sequences encoding human GM-CSF have been inserted between NcoI and BamHI sites in such a way that the initiation codon of the inserted sequences is placed precisely at the position normally occupied by the initiation codon for env translation, and minimal $3^{\prime}$ nontranslated sequences are included in the insert. Unlike many vectors commonly in use, MFG-S contains no sequences encoding a selectable marker. The psiCRIP cell line was utilized for the packaging of recombinant genomes into virus particles. High-titer stocks of recombinant viruses suitable for clinical use were generated from cultures of cells propagated in a closed-loop perfusion system designed for the mass cultures of anchorage-depend ent cells.

\section{Preparation of the single-cell suspensions and cultures from solid tumors}

Resected tumors were collected at surgery and transported in cold $\left(4^{\circ} \mathrm{C}\right)$ RPMI 1640 medium (GIBCO, Grand Island, NY) 
until processing. Necrotic tumor and connective tissue were trimmed and the remaining specimen minced into approximately 3- to 4- $\mathrm{mm}^{3}$ pieces with scissors in Hanks' balanced salt solution (HBSS) containing hyaluronidase (2.5 units $/ \mathrm{ml})$, collagenase $(0.5 \mathrm{mg} / \mathrm{ml})$, and deoxyribonucleas e $(0.05 \mathrm{mg} / \mathrm{ml})$ (all obtained from Sigma, St. Louis, MO). Routinely, $1 \mathrm{~g}$ of tumor specimen was digested in a minimum volume of $10 \mathrm{ml}$ of enzyme mixture. The resulting cell suspension was centrifuged $(500 \times g, 15 \mathrm{~min})$, filtered through a double layer of No. 100 nylon mesh, and resuspended in $100 \mathrm{ml}$ of RPMI 1640 medium containing $10 \%$ heat-inactivated human AB serum. Aliquots of tumor cells were cryopreserved in $90 \%$ human $\mathrm{AB}$ serum plus $10 \%$ dimethylsulfoxi de, at $-178^{\circ} \mathrm{C}$ in liquid nitrogen.

In addition to cryopreservation, tumor cells were suspended in approximately $60 \mathrm{ml}$ of complete medium (CM) in $150-\mathrm{cm}^{2}$ flasks with $1-5 \times 10^{6}$ freshly dissociated tumor cells/flask. CM is composed of RPMI 1640 with $10 \%$ human AB serum, $2 \mathrm{mM}$ glutamine, and gentamicin $(50 \mu \mathrm{g} / \mathrm{ml})$ (all from BioWhittaker, Walkersville, MD). Flasks were incubated at $37^{\circ} \mathrm{C}$ in $5 \% \mathrm{CO}_{2}$.

\section{Transduction of tumor cells with the MFG-S-GM-CSF viral particles}

Frozen virus supernatant was thawed in preparation for tumor cell transduction. Tumor cells were plated at $0.5-1 \times 10^{6}$ cells per $75-\mathrm{cm}^{2}$ flask and incubated at $37^{\circ} \mathrm{C}$ in a $5 \% \mathrm{CO}_{2}$ incubator for $18 \mathrm{hr}$ in $\mathrm{CM}$. Transductions were performed by aspirating the $\mathrm{CM}$ and replacing it with $10 \mathrm{ml}$ of MFG-S-GMCSF viral particles containing DEAE-dextran $(35 \mu \mathrm{g} / \mathrm{ml}$; Sigma) and incubated for $4 \mathrm{hr}$. The viral particles were then aspirated and replaced with $14 \mathrm{ml}$ of CM. GM-CSF production was assayed $24 \mathrm{hr}$ later by enzyme-linked immunosorbent assay (ELISA). If protein production was of high-enough quantity to prepare a tumor cell vaccine (i.e., greater than 40 $\mathrm{ng} / \mathrm{ml} / 10^{6}$ cells $/ 24 \mathrm{hr}$ ), the cells were then washed, harvested, and used for vaccine preparation as described below. A minimum of $10^{7}$ cells/vaccine will be prepared, which should represent at least $400 \mathrm{ng}$ of GM-CSF produced per $24 \mathrm{hr}$. The minimum level of GM-CSF production represents an equivalent amount of GM-CSF production identified in our animal model to enhance T cell sensitization in the draining LN (Arca et al., 1996a).

\section{Vaccination with GM-CSF-modified tumor cells}

Gene-modified tumor cells were irradiated with $5000 \mathrm{cGy}$. The cell suspension was adjusted so that a volume of $0.5 \mathrm{ml}$ of HBSS contained $1-2 \times 10^{7}$ irradiated tumor cells. The tumor cells were placed on ice until injection. Patients were immunized intradermally with $0.5 \mathrm{ml}$ of the cell suspension in one or two separate sites drained by an accessible nodal basin (i.e., inguinal region). Lymph nodes draining the sites of vaccination were selected so that the chosen LN group did not have clinically apparent metastases. Control vaccinations with a comparable number of WT irradiated tumor cells were inoculated intraderm ally in a separate site.

\section{Preparation of single cells from lymph nodes}

Patients underwent excision of vaccine-draining $\mathrm{LN} 7$ to 10 days after the vaccination. Identification of the immediate drain- ing LN was aided by the intradermal inoculation of blue dye (Lymphozurin) at the vaccine site as described by Morton et al. (1992). Single-cell suspensions of lymph node cells were prepared mechanically by methods previously described (Chang et al., 1997). After washing the cells in HBSS three times, they were placed in anti-CD 3 activation cultures immediately and the remaining $\mathrm{LN}$ cells were cryopreserved in liquid nitrogen for subsequent analysis and possible use in retreatments.

\section{Anti-CD3 activation and expansion}

Anti-CD3 activation and expansion required culturing cells an average of 15 days and subjecting the draining $\mathrm{LN}$ cells to primary and secondary culture procedures as previously described (Chang et al., 1997). For primary anti-CD3 activation, $5 \times 10^{8}$ lymphocytes were resuspended in serum-free medium (X-Vivo-15; BioWhittaker) at a concentration of $2 \times 10^{6}$ cells/ml and cultured in 24-well tissue culture plates $(2 \mathrm{ml} /$ well $)$ pretreated with OKT3. After $48 \mathrm{hr}$ of activation the cells were harvested and expanded in IL-2. Expansion was accomplished by resuspending anti-CD3-activated cells by diluting the primary activation medium with X-Vivo-15 supplemented with IL-2 (60 IU/ml; Chiron Therapeutics, Emeryville, CA) to a cell concentration of $3 \times 10^{5}$ cells $/ \mathrm{ml}$. These cells were placed in 3000-ml culture bags (Lifecell 3000; Fenwal, Deerfield, IL), each containing $500-850 \mathrm{ml}$ of medium. When the cell density reached approximately $10^{6}$ cells $/ \mathrm{ml}$, an additional 2 liters of serum-free X-Vivo-15 containing IL-2 (60 IU/ml) was added to each bag. Cells were grown to a maximum density (approximately $2 \times 10^{6}$ cells $/ \mathrm{ml}$ ), which took approximately 5 days.

The procedure to perform the secondary anti-CD3 activation represented a slight modification of the primary culture procedure. Briefly, $2 \times 10^{8}$ anti-CD3-activated cells derived from the primary culture procedure were suspended in $100 \mathrm{ml}$ of fresh medium in $150-\mathrm{cm}^{2}$ flasks with immobilized OKT3 MAb. After 1 day, the cells were harvested, washed, and expanded in serum-free medium (X-Vivo-15) containing IL-2 (60 IU/ml), using 3000-ml culture bags as previously described. Cells were harvested after approximately 7 days, when cells had reached their maximum density.

\section{Adoptive cellular therapy and IL-2 administration}

The lymphocytes were suspended in infusion medium, consisting of $190 \mathrm{ml}$ of normal saline, $10 \mathrm{ml}$ of human albumin (concentration, 25\% ; final concentration, $1.25 \%$ ) and 450,000 IU of IL-2. IL-2 was administered intravenously to enhance the activity of the activated cells and was given every $8 \mathrm{hr}$ for a total of 15 doses starting on the day of cell transfer. Infusion of IL-2 consisted of $360,000 \mathrm{IU} / \mathrm{kg}$ and commenced immediately after cell transfer. This schedule and dose of IL-2 has been associated with manageable and reversible side effects according to our previous experience with this regimen (Chang et al., 1997). The patients were treated as inpatients in the GCRC.

\section{Light microscopic and immunohistochemical analysis}

Besides routine light microscopic assessment of formalinfixed paraffin-embedded sections of tissue excised from the vaccine sites stained with hematoxylin-eosin, immunopathological examination was also performed. Serial sections of the 


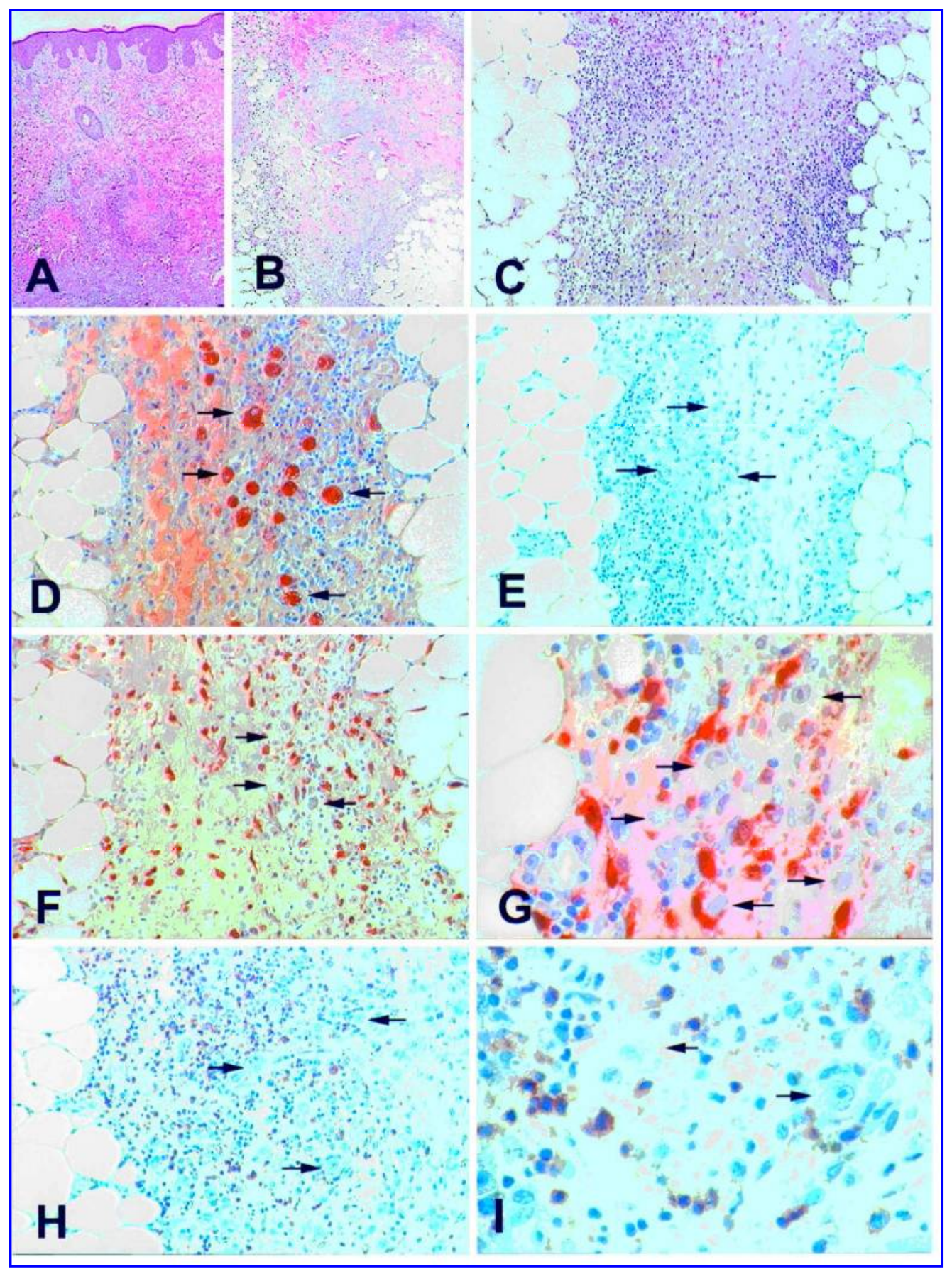

FIG. 1. Skin vaccine sites biopsied from patient 1, 7 days after injection with GM-CSF-transfected autologous melanoma cells. (A-C) Routine light microscopic appearance demonstrating mild epidermal acanthosis with prominent mid- and deep dermal mononuclear cell inflammatory infiltrate. This infiltrate included small and medium lymphocytes admixed with dendritic cells and neutrophils. Large nonpigmented melanom a tumor cells were present in deep dermis and accompanied the inflammatory infiltrate into the interlobular fibrous septae of subcutaneous adipose tissue. Small focal areas of necrosis with PMNs were also present. (D) Presence of melanoma cells was confirmed by S-100 immunoreactivity, including both nuclear and cytoplasmic staining (arrows) in deep subcutaneous tissue. (E) No MAC387-reactive macrophages were present in the subcutaneous tissue. (F and G) Numerous factor XIIIa-positive dermal dendrocytes are present surrounding melanoma tumor cells (arrows). (H and I) The majority of lymphocytes are CD45RO positive, belonging to the "memory" subset in proximity to melanoma cells (arrows). 


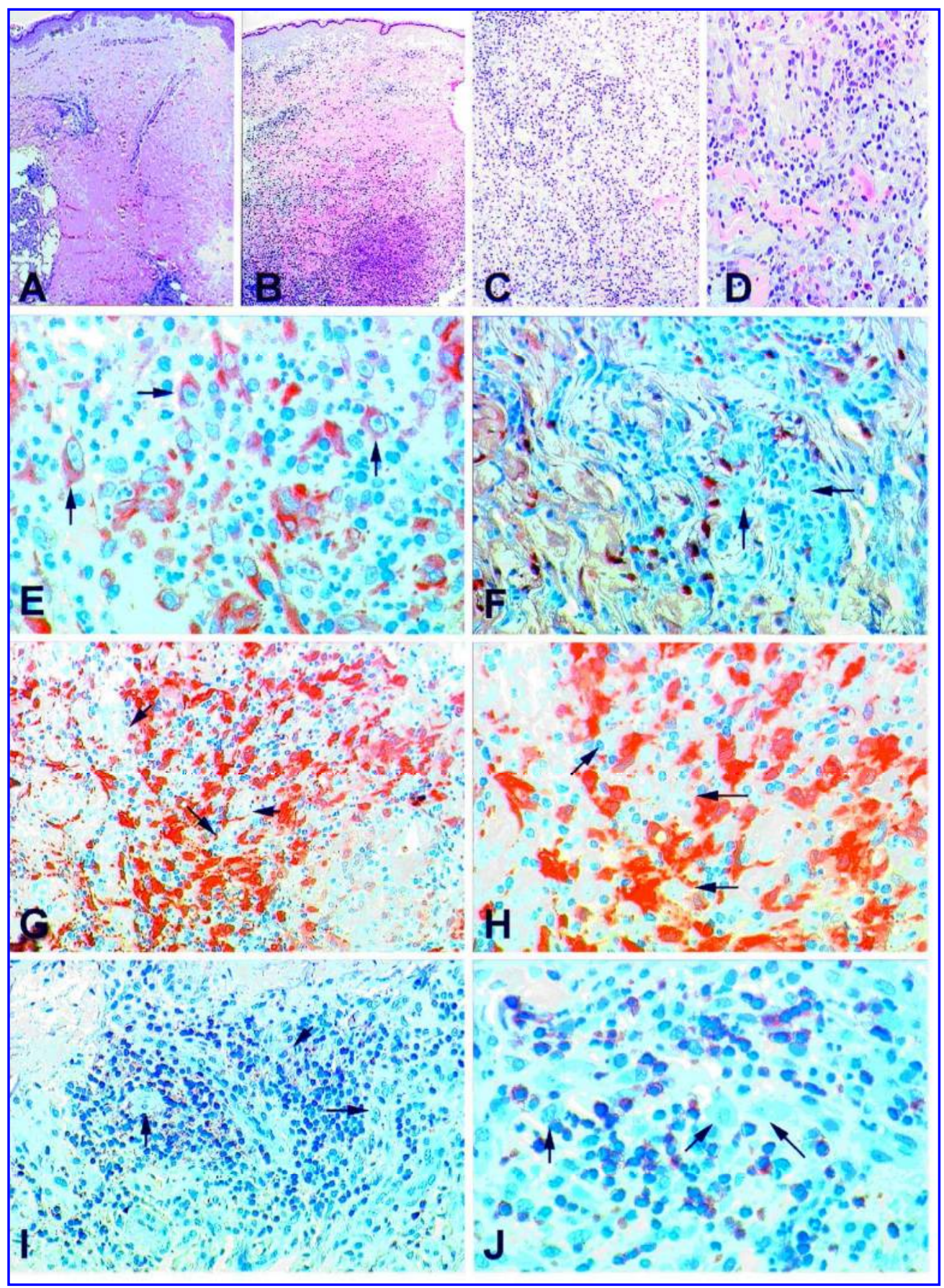

FIG. 2. Skin vaccine sites sampled from patient 2, 8 days after injection with either wild-type (A) or GM-CSF-transfected (B-J) autologous melanoma cells. (A) Routine light microscopic appearance of skin injected with mock-transfected melanoma cells with sparse superficial and deep perivascular lymphocyte infiltrate. (B-D) Routine light microscopic appearance demonstrating dense mononuclear cell infiltrate beginning in upper papillary dermis and extending into deep reticular dermis. This inflammatory infiltrate included lymphocyte, neutrophils, and eosinophils. (E) Presence of melanoma cells confirmed by vimentin immunoreactivity. Note the malignant cells have enlarged nuclei with vesicular chromatic and prominent nucleoli (arrows). (F) Occasional MAC387-positive macrophages are present near melanoma cells (arrows). (G and $\mathbf{H})$ Extensive increase in factor XIIIa-positive dermal dendrocytes with elongated cytoplasm ic processes in mid- and deep dermis closely associated with melanom a tumor cells (arrows). (I and J) Numerous CD45RO-positive "memory" T cells are present throughout the dermis admixed with melanom a tumor cells (arrows). 
paraffin blocks were placed on glass slides, and immunostained by a highly sensitive avidin-biotin immunoperoxidase technique with 3-amino-4-ethylc arbazole to produce a positive red reaction product. For detection of some antigens, tissue sections were microwaved in phosphate-buffer ed saline (PBS) for antigen retrieval prior to addition of primary antibodies. The following antibodies were used to detect their respective antigens: rabbit anti-serum against factor XIIIa was used to visualize dendritic cells (Calbiochem-Novabiochem, San Diego, CA); either rabbit anti-S100 or antivimentin Abs (obtained from Dako, Carpenteria, CA) were used to detect melanoma cells. Polymorphonuclear leukocytes (PMNs) and macrophages were immunostained with anti-MAC387 MAb (Dako), and distinguished by their morphology. Anti-CD3 pan T cell MAb and anti-CD45R0 MAb were used to detect memory-type $\mathrm{T}$ lymphocytes, and were purchased from Becton Dickinson (Mountain View, CA).

Detection of dermal DCs in both normal and diseased skin has been facilitated by immunostaining for the clotting factor XIIIa (Cerio et al., 1989). Since the initial recognition of a population of cells in the dermis with a dendritic morphology, it has become clear that such cells can function as antigen-presenting cells, and contribute to the dermal immune system (Headington, 1993). It is now well established that there are several different types of dermal dendritic cells, and that the subset that expresses factor XIIIa can function as professional antigen-presenting cells (Nestle et al., 1993).

A semiquantitative assessment of the relative intensity of the cellular infiltrates was scored on a $1-5$ point scale, with $1+$ being considered a mild degree of infiltration, $3+$ being considered as moderately intense, and $5+$ representing severely intense infiltrate for the respective cell types as determined by a single observer.

\section{Immune functional analysis of VPLN cells}

Immune reactivity of activated WT and GM-CSF VPLN cells was assessed by measurement of secretion of cytokines in response to irradiated autologous tumor cells as previously described (Chang et al., 1997; Li et al., 1999). For analytical pur- poses, VPLN cells were enriched for $\mathrm{CD} 3^{+} \mathrm{T}$ cells by nylon wool columns and fractionated for $\mathrm{CD} 4^{+}$or $\mathrm{CD} 8^{+}$cells by positive selection with paramagnetic beads as previously described (Li et al., 1999). After T cell activation and expansion, $2 \times 10^{6}$ activated VPLN cells were cocultured with $0.5 \times 10^{6}$ irradiated autologous tumor cells in $2 \mathrm{ml}$ of medium placed in individual wells of a 24-well culture plate. The assay medium consisted of RPMI 1640 supplemented with $10 \%$ fetal bovine serum, 1 $\mathrm{m} M$ sodium pyruvate, $1 \times$ nonessential amino acids, penicillin (100 units $/ \mathrm{ml})$, streptomycin $(100 \mu \mathrm{g} / \mathrm{ml})$, gentamicin sulfate (50 $\mu \mathrm{g} / \mathrm{ml})$, Fungizone $(0.5 \mu \mathrm{g} / \mathrm{ml}), 0.05 \mathrm{~m} M$ 2-mercaptoethanol (all from BioWhittaker), and IL-2 (4 IU/ml). Tumor cells were irradiated with $20,000 \mathrm{cGy}$ using a ${ }^{137} \mathrm{Cs}$ source $(500$ cGy/min, gamma cell irradiator; Atomic Energy of Canada, Mississauga, Ontario, Canada). After 48 hr, culture supernatants were collected and centrifuged at $1500 \mathrm{rpm}$ for $5 \mathrm{~min}$ to separate any cells. Culture supernatants were then measured for interferon $\gamma(\mathrm{IFN}-\gamma)$, GM-CSF, and IL-10 with commercially available ELISA reagents (PharMingen, San Diego, CA), according to the manufacturer directions. For GM-CSF, a standard curve starting at $20,000 \mathrm{pg} / \mathrm{ml}$ with serial twofold dilutions was performed. For IFN- $\gamma$ and IL-10, standard curves starting at $10,000 \mathrm{pg} / \mathrm{ml}$ were established in a similar fashion. The threshold of detection for each cytokine was approximately $100 \mathrm{pg} / \mathrm{ml}$. Experimental values were computed after cytokine release by $\mathrm{T}$ cells or tumor cells alone was subtracted.

Inhibition of $\mathrm{T}$ cell recognition of tumor-associated antigen on target tumor cells was examined with anti-class I (HLA-A, $-\mathrm{B}$, and $-\mathrm{C}$ ) MAb and anti-class II (HLA-DR, -DP, -DQ) MAb (PharMingen) in the cytokine release assay.

\section{RESULTS}

\section{Transduction of tumor cells and plasma levels}

A total of seven patients had tumor surgically removed and placed into tissue culture to develop proliferating cells. Approximately 3 weeks after placem ent into culture, the cells were transduced with retrovirus. Five of the seven attempts resulted

Table 1. Summary of Immunohistochemical Analysis of Vaccine Sites

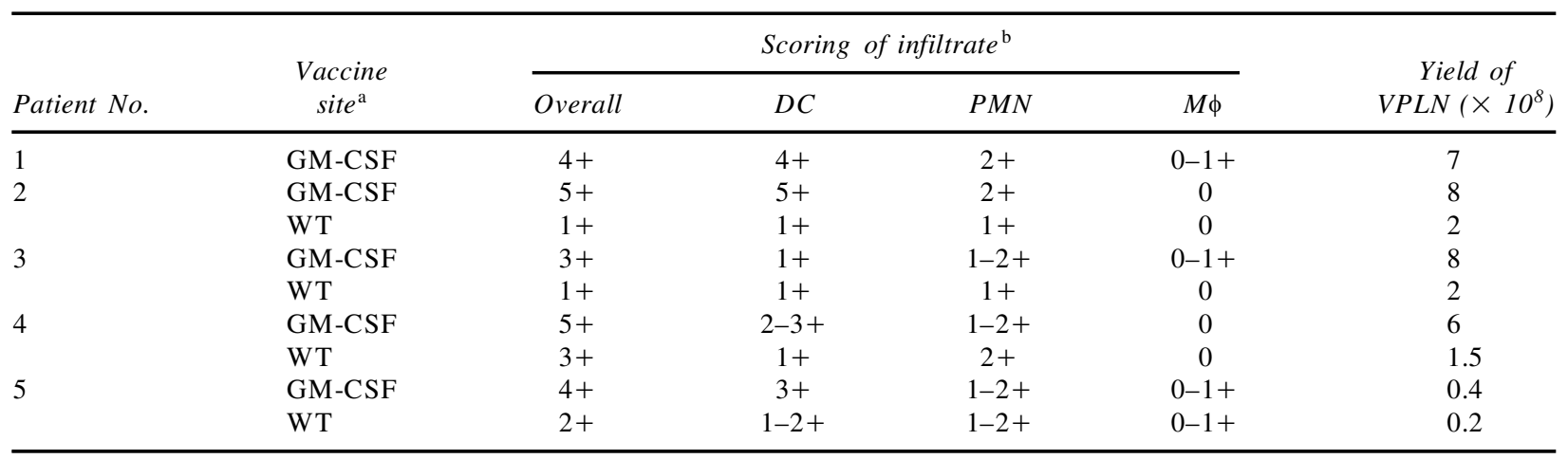

${ }^{a}$ GM-CSF-transduced (GM-CSF) or nontransduced wild-type (WT) tumor cells were irradiated and inoculated intradermally into opposite thighs. Approximately 7-8 days later, the vaccine sites were harvested at the time of VPLN excision.

${ }^{\mathrm{b}}$ The infiltrate was scored on a $1-5$ point scale with $1+$ being mild, $3+$ moderate, and $5+$ severe. The overall infiltrate was scored on the basis of H\&E staining. DC, dendritic cells; PMN, polymorphonucle ar cells; M $\phi$, macrophages. 
in transgenic GM-CSF production by tumor cells whereas, in the remaining two patients, cell death was observed. For patients $1-5$, the amount of transgenic GM-CSF protein produced by the tumor cells was $56,86,62,96$, and $100 \mathrm{ng} / 10^{6}$ cells/24 hr, respectively.

Between $1 \times 10^{7}$ and $2 \times 10^{7}$ irradiated tumor cells were inoculated intradermally in the anterior thigh skin. Mild induration with skin erythema was observed approximately 7-10 days later at the time of VPLN harvest. There was no skin ulceration or systemic toxicity associated with the vaccines. Plasma levels of GM-CSF were undetectable by ELISA for all patients when assessed 7-10 days after vaccination.

\section{Vaccination sites and yield of VPLN}

At the time of vaccine-primed $\mathrm{LN}$ removal, the intradermal vaccine sites were also excised for immunohistoch emical analysis. Antibodies were used to identify melanoma tumor cells, dendritic cells (DCs), and tissue macrophages (M $\phi)$. Illustrations of the vaccine sites are depicted in Figs. 1 and 2. In patient 1 (Fig. 1), routine light microscopy revealed mild epidermal acanthosis with a prominent mid- and deep dermal mononuclear cell inflammatory infiltrate (Fig. 1A-C). By immunohistochemical staining, specific cell populations were identified. These included tum or cells (Fig. 1D), which were surrounded by DCs (Fig. 1F and G). CD45RO-positive memory cells comprised the majority of the lymphocytes within the infiltrate (Fig. 1H and I). No MAC387-reactive macrophages were present in the infiltrate. In patients $2-5$, bilateral anterior thigh vaccinations were performed with one side receiving the transduced tumor cells; and the contralateral side receiving irradiated, nontransduced wild-type tumor cells. Both vaccine sites were excised at the time of LN harvest and the cellular infiltrates compared. In Fig. 2, the vaccine sites of patient 2 are illustrated for comparison. Routine light microscopy of the nontransduced wild-type vaccine site revealed a sparse superficial and deep perivascular lymphocyte infiltrate (Fig. 2A). In contrast, the GM-CSF-transduced vaccine site demonstrated a dense mononuclear cell infiltrate beginning in the upper papillary dermis and extending into the deep reticular dermis (Fig. 2B-D). This infiltrate includes lymphocytes, neutrophils, and eosinophils. By immunohistoch emical analysis, extensive DC infiltration was noted surrounding melanoma tumor cells (Fig. $2 \mathrm{G}$ and $\mathrm{H}$ ). Again, numerous CD45RO-positive "memory" $\mathrm{T}$ cells were present throughout the dermis admixed with tumor cells (Fig. 2I and J). Occasional MAC387-positive macrophages were present near tumor cells (Fig. 2F).

The histologic findings are summarized in Table 1. Patient 3 did not have an increased infiltration of DCs at the transduced vaccine site compared with the nontransduced vaccine site; this was thought to be due to the subcutaneous inoculation of the vaccine. By contrast, all of the other patients had their vaccines inoculated intradermally. As depicted in Table 1, GM-CSF secretion consistently resulted in the infiltration of DCs to the vaccine site in the patients given an intradermal inoculation of tumor cells. Compared with the WT vaccine site, there were no differences in infiltration of PMNs or macrophages.

The yields of VPLN cells draining the different vaccine sites are also summarized in Table 1. In all four patients into whom both WT and GM-CSF-transduced tumor cells were inoculated,

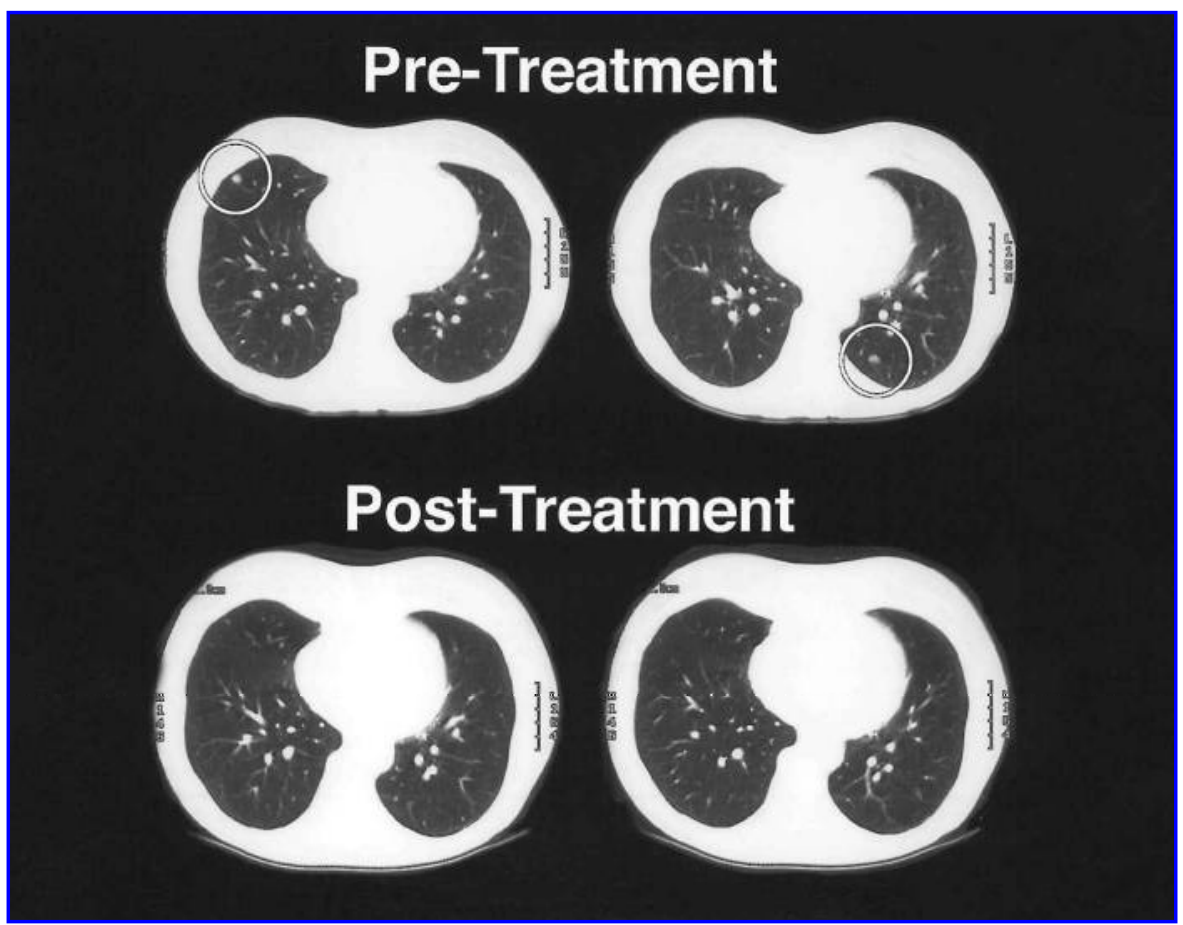

FIG. 3. CT scan of patient 2 before and after therapy with GM-CSF-induced VPLN cells. Top: Two pulmonary nodules present before therapy (circles). Bottom: Complete regression of these nodules. This patient also had complete regression of a mediastinal lymph node involved with tumor (not shown). 
there was a greater yield of VPLN cells elicited by the transduced tumor cell vaccine. The mean number $( \pm S E M)$ of GM-CSF and WT VPLN cells was $5.9( \pm 1.4) \times 10^{8}$ and $1.4 \pm 0.4) \times 10^{8}$ cells, respectively $(p<0.01$, paired comparison $t$ test).

\section{Summary of patients and immunological function}

Patient 1. Patient was a 42-year-old woman with metastatic disease in multiple subcutaneous sites, lung, liver, spleen, and lymph nodes. She received irradiated transduced tumor cells and had vaccine-prim ed lymph node (VPLN) cells harvested 8 days later. She went on to receive approximately $2 \times 10^{10} \mathrm{ac}-$ tivated VPLN cells intravenously along with the concomitant administration of IL-2. After five doses of IL-2, treatment had to be discontinued because of hypotension and low urine output. This resolved after several days. Prior to discharge she became acutely comatose. A CT scan of the brain revealed a left temporal lobe intracerebral bleed. Because of the patient's extensive metastatic disease the patient was allowed to expire. An autopsy was performed and she was found to have a small focus of metastatic disease in the brain, causing the bleed. The disease was occult since a pretreatment brain CT scan had been negative.

Functional immune studies of this patient's VPLNs were performed. A tumor line was established and the patient was found to be MHC class I positive, but class II negative. Fractionated $\mathrm{CD}^{+}$and $\mathrm{CD}^{+}{ }^{+} \mathrm{T}$ cell subpopulations were assessed for immune function. There was no cytokine release (IFN- $\gamma$, GMCSF, or IL-10) of these activated T cell populations in response to autologous tumor cells (data not shown).

Patient 2. Patient 2 is a 57 -year-old woman with metastatic melanoma to lung and mediastinal lymph nodes. She went on to receive $3 \times 10^{10}$ VPLN cells with 14 doses of IL-2. After 2 months of follow-up, CT scans revealed a partial response. She was retreated with a similar number of VPLN cells and IL-2 and went on to have a complete response of all evaluable disease (Fig. 3). Approximately 4 months after her second treatment, she went on to receive 15 more doses of IL-2. She has remained in complete remission for $36+$ months. A cell line could not be established from this patient's tumor and hence, functional immune studies were not performed.

Patient 3. Patient 3 was a 69 -year-old woman with metastatic ocular melanoma to her lungs. She went on to receive VPLN cells with 15 doses of IL-2. In follow-up her disease was noted to have progressed and she was removed from the protocol. Her tumor cells failed to establish a tumor line and therefore immune analysis of her VPLN could not be performed.

Patient 4. Patient 4 was a 40 -year-old woman with metastatic disease involving liver, mesenteric nodes, and subcutaneous nodules. She received approxim ately $2 \times 10^{10}$ VPLN cells and 15 doses of IL-2. Her disease remained stable for 2 months, at which time it was decided to retreat her. During the period of VPLN cell activation for this second treatment, she developed symptomatic brain metastases and was taken off protocol.

We were able to establish a tumor line for functional immune studies of her VPLN cells. The tumor cell line expressed both MHC class I and II molecules. Fractionated $\mathrm{CD}^{+}$and
$\mathrm{CD}^{+} \mathrm{T}$ cell subpopulations were examined for cytokine release. As shown in Fig. 4, the $\mathrm{CD}^{+}$cells induced by the GMCSF-transduced vaccine released IFN- $\gamma$, GM-CSF, and IL-10 in response to autologous tumor cells. This response was relatively specific since an allogeneic tumor line failed to stimulate the same response. There was minimal cytokine released by $\mathrm{CD}^{+} \mathrm{T}$ cells (Fig. 4). The addition of blocking MAb demonstrated the response to be MHC class II restricted.

This patient was vaccinated with both WT and GM-CSFtransduced tumor cells. This allowed us to compare the immune function of WT and GM-CSF VPLN cells in response to autologous tumor. As summarized in Fig. 5, the WT tumor cells induced VPLN cells with slightly greater IFN- $\gamma$ and GM-CSF

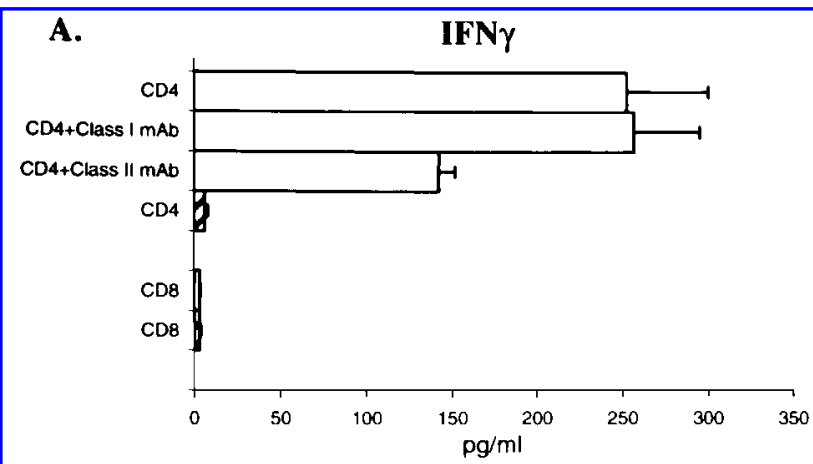

B.

GM-CSF
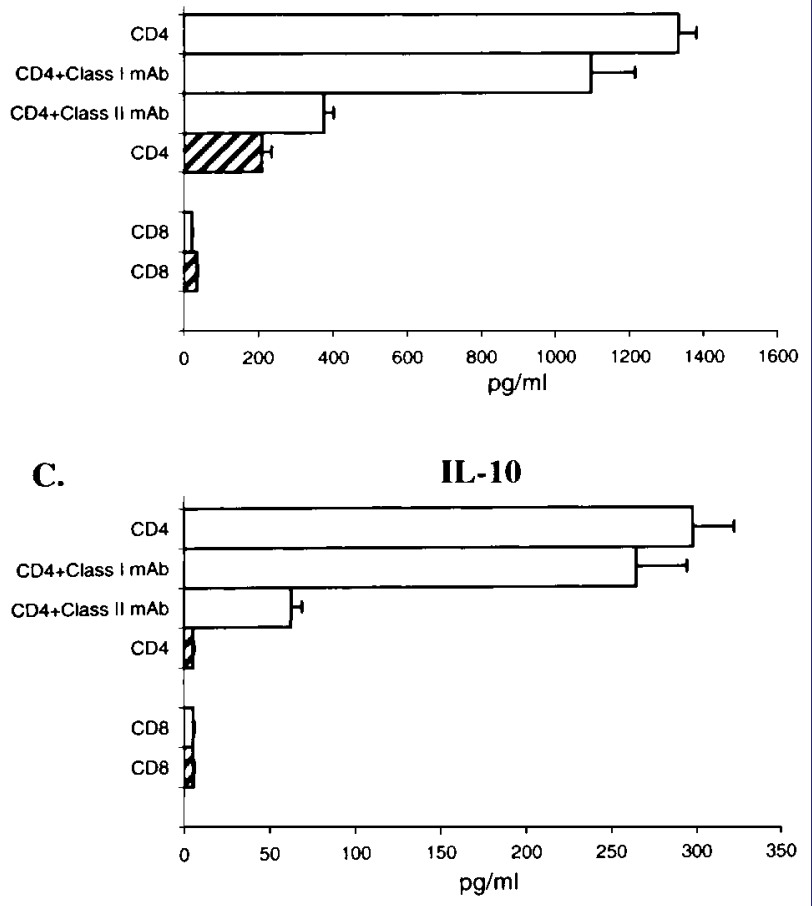

FIG. 4. Cytokine release by GM-CSF-induced VPLN cells from patient 4 in response to autologous (open columns) or allogeneic (hatched columns) tumor stimulator cells. (A)-(C) demonstrate IFN- $\gamma$, GM-CSF, and IL-10 release, respectively, by $\mathrm{CD} 4^{+}$VPLN cells in response to autologous tumor cells that were MHC class II restricted. 
cytokine release responses to autologous tumor compared with GM-CSF-transduced tumor cells. What was striking was the diminished IL-10 release by $\mathrm{CD}^{+}{ }^{+}$cells from GM-CSF VPLN compared with WT VPLN.

Patient 5. Patient 5 was a 46-year-old woman with metastatic disease involving lung, liver, and subcutaneous sites. During the time of transduction of tumor cells and subsequent vaccination, the patient developed rapidly progressive disease in her lungs. She had to be hospitalized for pneumonia prior to her planned cell infusion. Because of her subsequent poor performance status, it was felt she could not tolerate the cell infusion and IL-2 and was taken off the protocol.

A tumor line established from this patient expressed both MHC class I and II molecules. This patient was also vaccinated with WT and GM-CSF-transduced tumor cells, which permitted comparison of the different VPLN populations. Purified $\mathrm{CD}^{+} \mathrm{T}$ cells were analyzed and are summarized in Fig. 6. Because of the limited number of VPLN cells, fractionation of $\mathrm{CD}^{+}{ }^{+}$and $\mathrm{CD}^{+}{ }^{+} \mathrm{T}$ cell subsets could not be performed. The GM-CSF VPLN cells released significantly greater amounts of

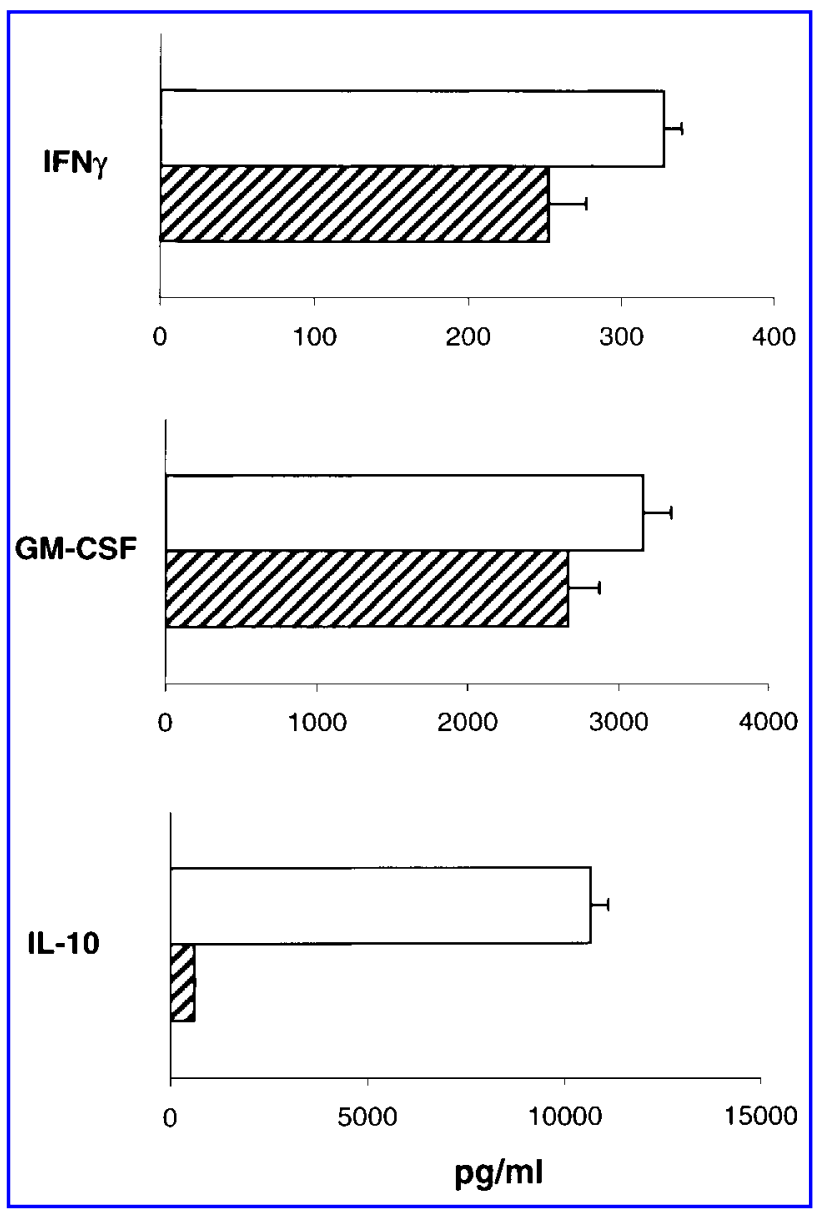

FIG. 5. Comparison of GM-CSF- versus WT-induced CD4 ${ }^{+}$ VPLN cells from patient 4 . There was significantly less IL-10 released by GM-CSF-induced VPLN cells compared with WT VPLN cells. Open columns, wild type; hatched columns, GMCSF.

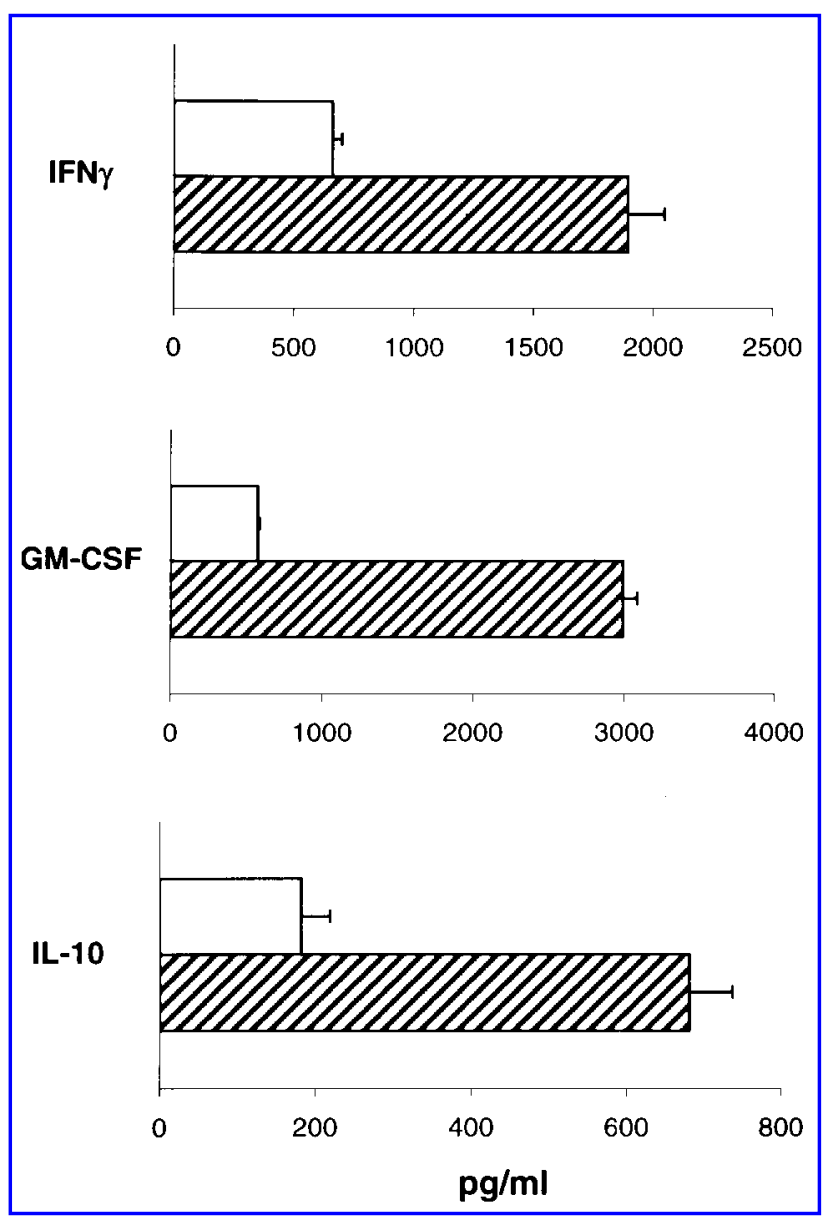

FIG. 6. Comparison of GM-CSF- versus WT-induced CD3 ${ }^{+}$ VPLN cells from patient 5 . There was significantly greater release of IFN- $\gamma$, GM-CSF, and IL-10 by GM-CSF-induced VPLN cells compared with WT VPLN cells. Open columns, wild type; hatched columns, GM-CSF.

IFN- $\gamma$, GM-CSF, and IL-10 compared with WT VPLN cells in response to autologous tumor.

A summary of the toxicities that were observed in the patients receiving activated VPLN cells plus IL-2 are presented in Table 2. The toxicities were associated with the IL-2 administration and were reversible. The death of patient 1 was secondary to progressive disease.

\section{DISCUSSION}

Murine studies have demonstrated that GM-CSF-transduced tum or cells used as a vaccine can induce protective immunity to a subsequent challenge of tumor cells (Dranoff et al., 1993). GM-CSF appears to be a potent immune adjuvant in the induction of $\mathrm{T}$ cell immunity, which has been postulated to be due to the recruitment of dendritic cells and/or their activation as antigen-presenting cells. However, the use of cytokine-transduced tumor cells as vaccines to treat established tumors has been limited. There are only a few reports demonstrating that established tumors can be successfully treated by immunization 
Table 2. Summary of Toxicities ${ }^{\mathrm{a}}$

\begin{tabular}{|c|c|c|c|c|c|}
\hline \multirow[b]{2}{*}{ Toxicity } & \multicolumn{5}{|c|}{ Grade of toxicity } \\
\hline & 1 & 2 & 3 & 4 & 5 \\
\hline \multicolumn{6}{|l|}{ Bone marrow/blood } \\
\hline Lymphocytes & & & & 3 & \\
\hline Platelet & 2 & 1 & & & \\
\hline Hemoglobin & & 2 & 1 & & \\
\hline \multicolumn{6}{|l|}{ Gastrointestinal } \\
\hline Nausea & 2 & 1 & & & \\
\hline Vomiting & & 2 & & & \\
\hline \multicolumn{6}{|l|}{ Liver } \\
\hline Bilirubin & & & 2 & 1 & \\
\hline Transaminases & 1 & 2 & 1 & & \\
\hline Alkaline phosphatase & 2 & 2 & & & \\
\hline \multicolumn{6}{|l|}{ Renal } \\
\hline Creatinine & & 1 & 1 & 1 & \\
\hline Skin & 2 & 1 & & & \\
\hline \multicolumn{6}{|l|}{ Blood pressure } \\
\hline Hypotension & 1 & & 3 & & \\
\hline Weight gain & 1 & 1 & & & \\
\hline \multicolumn{6}{|l|}{ Metabolic } \\
\hline Hyperglycemia & 1 & 1 & & & \\
\hline Hypocalcemia & & 1 & 3 & & \\
\hline Fever & 1 & 1 & & & \\
\hline Neurologic & & & & & $1^{b}$ \\
\hline
\end{tabular}

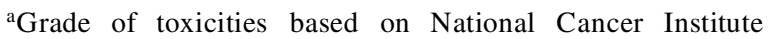
Common Toxicity Criteria. The number of patients experiencing the highest grade of toxicity is recorded. Four patients received activated lymph node cells and IL-2 and comprise the patient population summarized here.

${ }^{\mathrm{b}}$ Coma secondary to cerebral hemorrhage from metastatic cancer disease (see Results).

with cytokine-secreting tumor cells (Golumbek et al., 1991; Connor et al., 1993; Nagai et al., 1998). Our laboratory has taken a different approach in treating established tumors by employing ex vivo activated $\mathrm{T}$ cells for adoptive immunotherapy. These $\mathrm{T}$ cells are generated in vivo by active immunization with vaccines composed of tumor cells admixed with bacterial immune adjuvants or genetically modified tumor cells engineered to secrete cytokines.

In a direct comparison, we found that GM-CSF secreted by tumor cells was superior to the use of a bacterial adjuvant in sensitizing $\mathrm{T}$ cells to tumor antigen in vivo (Arca et al., 1996a). In these studies, we utilized the poorly immunogenic D5 melanoma line, from which we produced several stable GMCSF-secreting clones by retroviral transduction. The D5 melanom a lacks both class I and II MHC molecules. We compared the GM-CSF transfectant with wild-type (WT) tumor admixed with Corynebacteriu $m$ parvum in the induction of tumor-reactive $\mathrm{T}$ cells derived from lymph nodes draining the sites of intradermal vaccinations. These vaccine-primed lymph node cells were subsequently activated in vitro by an antiCD3/IL-2 method we have previously described, which allows expansion of the cells while maintaining their antitumor reactivity (Yoshizawa et al., 1991). The antitumor reactivity of the VPLN cells was assessed in an adoptive immunotherapy model of established pulmonary metastases. GM-CSF-induced VPLN cells were significantly better than VPLN cells induced by the bacterial adjuvant in mediating tumor regression. When we examined other cytokines introduced into the D5 melanoma by gene transfer (i.e., IL-2, IFN- $\gamma$, or IL-4), GM-CSF was superior in the induction of $\mathrm{T}$ cell immunity (Arca et al., 1996b).

Our clinical trial demonstrated that a significant influx of dendritic cells was recruited to the site of the GM-CSF-secreting vaccine. This was a result of the local elaboration of cytokine since we also injected the WT vaccine as a control for comparative analysis in four patients. Three of the four patients had a greater influx of dendritic cells at the GM-CSF vaccine site compared with the WT vaccine. In the one patient who did not manifest this finding, the vaccination was inoculated subcutaneously rather than intradermally as identified by immunohistochem ical analysis. We postulate that the location of vaccine inoculation may be important and that the dendritic cells migrate from the dermis into the vaccine sites.

Of more interest was the evaluation of immune function of the VPLN cells generated by the vaccines. There was a diversity of immune responses. Unfortunately, we were unable to enroll more patients in this study because of a limited supply of GM-CSF retroviral vector. Nonetheless, there were some interesting observations that may be useful in the design of future studies. In individual patients, we were able to measure different immune responses from regional nodes draining WT versus GM-CSF-secreting tumor cell vaccination sites. In patient $4, \mathrm{CD}^{+} \mathrm{T}$ cells derived from the GM-CSF VPLN cells had significantly depressed IL-10 elaboration compared with WT VPLN cells. The secretion of IFN- $\gamma$ and GM-CSF was actually comparable between WT VPLN and GM-CSF VPLN cells in this same patient. In animal models, we have demonstrated that immune $\mathrm{T}$ cells that secrete type 2 cytokines (i.e., IL-10) have a suppressive interaction on antitumor reactivity when used in adoptive immunotherapy; where the elaboration of type 1 cytokines (i.e., IFN- $\gamma$ ) or GM-CSF can facilitate tumor regression (Aruga et al., 1997). Hence, the generation of effector T cells with minimal IL-10 elaboration would be predicted to be clinically useful. In patient 5 , we noted that $\mathrm{CD}^{+}$ $\mathrm{T}$ cells from GM-CSF VPLN had upregulated secretion of IFN$\gamma$, GM-CSF, and IL-10 compared with WT VPLN. This would suggest that the local elaboration of GM-CSF at the vaccine site had a significant adjuvant effect on several different $\mathrm{T}$ cell populations. We had insufficient numbers of cells from this patient to perform $\mathrm{CD}^{+}$and $\mathrm{CD}^{+} \mathrm{T}$ cell separations. In patient 1 , we did not administer a control vaccine of WT tumor cells. However, the GM-CSF VPLN cells failed to secrete any detectable cytokines in response to autologous tumor, suggesting that there may have been host factors that caused an immune suppression.

The use of GM-CSF-transduced autologous tumor cells administered as a vaccine for the treatment of human cancer has been previously reported as a case report. Ellem et al. (1997) treated a patient with stage IV melanoma with multiple inoculations of autologous tumor cells genetically modified to secrete GM-CSF. A mixed tumor response was observed, and a strong delayed-type hypersensitivity reaction to autologous tumor cells identified. In the peripheral circulation, both a $\mathrm{CD} 8^{+}$ and $\mathrm{CD}^{+}$cellular response to autologous tumor was observed over a transient period. As a case report, it is hard to draw definitive conclusions about the immunologic effects of this type 
of vaccine. Nevertheless, this case demonstrated increased immune reactivity of PBLs to autologous tumor over the course of several immunizations. As suggested by our data, the immune reactivity can be different between patients because of diverse clinical factors. Correlative studies with larger numbers of patients need to be performed in order to identify which immune param eters can predict the therapeutic efficacy of a particular vaccine approach.

The role of GM-CSF secreted locally at the tumor vaccination site may mediate its regional immune adjuvant effect by several mechanisms. Our data strongly suggest that recruitment of DCs occurs within the vaccine site as a result of GM-CSF protein secretion. Hence, the presence of increased numbers of DCs may result in increased antigen processing and presentation locally. We have also documented in a preclinical study that there is an associated migration of DCs to the immediate draining lymph nodes when tumor vaccination involves GM$\mathrm{CSF}$ as an adjuvant elaborated locally in the skin (Tanigawa et $a l ., 2000)$. Another mechanism by which GM-CSF may act as an effective adjuvant is by correction of any suppressed antigen-presenting capacity that has been observed in the cancerbearing host. We have previously observed that dermal DCs in human basal cell and squamous cell carcinomas fail to express important costimulatory molecules (i.e., CD80 and CD86) and have defective antigen-presenting capacity, which could be corrected by the exposure to GM-CSF (Nestle et al., 1997a,b).

Soluble GM-CSF has been used as an adjuvant with an autologous tumor cell vaccine in patients with metastatic melanoma. Leong et al. reported the use of soluble GM-CSF inoculated intradermally over the course of several days at vaccine sites composed of autologous tumor cells and bacillus Calmette-Guérin (BCG) (Leong et al., 1999). In that study 4 of 20 patients were documented to have complete or partial responses. Immunologic data to measure cellular responses to tumor were not assessed. Even though a separate cohort of patients vaccinated with tumor cells and BCG had no clinical responses, the contribution of GM-CSF cannot be assumed since it was not a prospective, randomized trial. However, it did suggest that GM-CSF may be an important local adjuvant in the induction of tumor regression responses. The advantage of utilizing genetically modified tumor cells, as opposed to soluble cytokine protein, is the avoidance of multiple injections.

One conclusion we can draw from this experience is that GM-CSF appears to be elaborated locally as indicated by the dendritic cell infiltration, and that it results in a larger accumulation of lymphoid cells in the immediate draining lymph node basin. Furtherm ore, our data indicate that the local elaboration of GM-CSF can influence the sensitization of tum or reactive $\mathrm{T}$ cells in the draining $\mathrm{LN}$. The one complete tumor response we have observed in the patients we have treated suggests that this may provide a method to generate tumor-reactive $\mathrm{T}$ cells capable of mediating regression of established tumor metastases. We cannot exclude the possibility that the tumor response that was observed was due to the IL-2 administration. A phase II trial needs to be conducted to ascertain what response rate is associated with this therapy in order to determine if a randomized trial comparing IL-2 treatment alone is justified. We are currently evaluating gene gun methods to introduce GM-CSF plasmid into tumor cells as a sim- pler way to generate vaccine-primed lymph nodes that might be applied in a phase II study (Tanigawa et al., 2000).

\section{ACKNOWLEDGMENTS}

This study was supported in party by NIH Grants PO1 CA59327 and MO1RR00042, the Gillson Longenbaugh Foundation, and the Elsa Pardee Foundation. The authors thank Jodi Hargreaves for excellent assistance in the preparation of the manuscript.

\section{REFERENCES}

ARCA, M.J., KRAUSS, J.C., ARUGA, A., CAMERON, M.J., SHU, S., and CHANG, A.E. (1996a). Therapeutic efficacy of T cells derived from lymph nodes draining a poorly immunogenic tumor transduced to secrete granulocyte-macrophage colony-stimulating factor. Cancer Gene Ther. 3, 39-47.

ARCA, M.J., KRAUSS, J.C., STROME, S.E., CAMERON, M.J., and CHANG, A.E. (1996b). Diverse manifestations of tumorigenicity and immunogenicity displayed by the poorly immunogenic B16-BL6 melanoma transduced with cytokine genes. Cancer Immunol. Immunother. 42, 237-245.

ARUGA, A., ARUGA, E., TANIGAWA, K., BISHOP, D.K., SONDAK, V.K., and CHANG, A.E. (1997). Type 1 versus type 2 cytokine release by $\mathrm{V} \beta \mathrm{T}$ cell subpopulations determines in vivo antitumor reactivity: IL-10 mediates a suppressive role. J. Immunol. 159, 664-673.

ASHER, A.L., MULÉ, J.J., KASID, A., RESTIFO, N.P., SALO, J.C., REICHERT, C.M., JAFFE, G., FENDLY, B., KRIEGLER, M., and ROSENBERG, S.A. (1991). Murine tumor cells transduced with the gene for tumor necrosis factor- $\alpha$. Evidence for paracrine immune effects of tumor necrosis factor against tumors. J. Immunol. 146, 3227-3247.

CERIO, R., GRIFFITHS, C.E.M., COOPER, K.D., NICKOLOFF, B.J., and HEADINGTON, J.T. (1989). Characterization of factor XIIIa positive dermal dendritic cells in normal and inflamed skin. Br. J. Dermatol. 121, 421-433.

CHANG, A.E., SONDAK, V.K., BISHOP, D.K., NICKOLOFF, B.J., MULLIGAN, R.C., and MULÉ, J.J. (1996). Adoptive immunotherapy of cancer with activated lymph node cells primed in vivo with autologous tumor cells transduced with the GM-CSF gene. Gene Ther. 7, 773-792.

CHANG, A.E., ARUGA, A., CAMERON, M.J., SONDAK, V.K., NORMOLLE, D.P., FOX, B.A., and SHU, S.Y. (1997). Adoptive immunotherapy with vaccine-primed lymph node cells secondarily activated with anti-CD3 and interleukin-2. J. Clin. Oncol. 15, 796-807.

CHOU, T., BERTERA, S., CHANG, A.E., and SHU, S.Y. (1988a). Adoptive immunotherapy of microscopic and advanced visceral metastases with in vitro sensitized lymphoid cells from mice bearing progressive tumors. J. Immunol. 141, 1775-1781.

CHOU, T., CHANG, A.E., and SHU, S. (1988b). Generation of therapeutic $\mathrm{T}$ lymphocytes from tumor-bearing mice by in vitro sensitization: Culture requirements and characterization of immunologic specificity. J. Immunol. 140, 2453-2461.

COLOMBO, M.P., FERRARI, G., STOPPACCIARO, A., PARENZA, M., ROdOlFO, M., MAVILIO, F., and PARMiANI, G. (1991). Granulocyte colony-stimulating factor gene transfer suppresses tumorigenicity of a murine adenocarcinom a in vivo. J. Exp. Med. 173, 889-897.

CONNOR, J., BANNERJI, R., SAITO, S., HESTON, W., FAIR, W., 
and GILBOA, E. (1993). Regression of bladder tumors in mice treated with interleukin 2 gene-modified tumor cells. J. Exp. Med. 177, 1127-1134.

DONAHUE, R.E., WANG, E.A., STONE, D.K., KAMEN, E., WONG, G.G., SEHGAL, P.K., NATHAN, D.G., and CLARK, S.C. (1986). Stimulation of haematopoiesis in primates by continuous infusion of recombinant human GM-CSF. Nature (London) 321, 872-875.

DRANOFF, G., JAFFE, E., LAZENBY, A., GOLUMBEK, P., LEVITSKY, H., BROSE, K., JACKSON, V., HAMADA, H., PARDOLL, D.M., and MULLIGAN, R.C. (1993). Vaccination with irradiated tumor cells engineered to secrete murine granulocyte-macrophage colony-stimulat ing factor stimulates potent, specific, and long-lasting antitumor immunity. Proc. Natl. Acad. Sci. U.S.A. 90, 3539-3543.

ELLEM, K.A., O'ROURKE, M.G., JOHNSON, G.R., PARRY, G., MISKO, I.S., SCHMIDT, C.W., PARSONS, P.G., BURROWS, S.R., CROSS, S., FELL, A., LI, C.L., BELL, J.R., DUBOIS, P.J., MOSS, D.J., GOOD, M.F., KELSO, A., COHEN, L.K., DRANOFF, G., and MULLIGAN, R.C. (1997). A case report: Immune responses and clinical course of the first human use of granulocyte/macrophagecolony-stimulat ing-factor-transduced autologous melanoma cells for immunotherap y. Cancer Immunol. Immunother. 44, 10-20.

FEARON, E.R., PARDOLL, D.M., ITAYA, T., GOLUMBEK, P., LEVITSKY, H.I., SIMONS, J.W., KARASUYAMA, H., VOGELSTEIN, B., and FROST, P. (1990). Interleukin-2 production by tumor cells bypasses $\mathrm{T}$ helper function in the generation of an antitumor response. Cell 60, 397-403.

FIELDS, R.C., SHIMIZU, K., and MULÉ, J.J. (1998). Murine dendritic cells pulsed with whole tumor lysates mediate potent antitumor immune responses in vitro and in vivo. Proc. Natl. Acad. Sci. U.S.A. 95, 9482-9487.

GANSBACHER, B., ZIER, K., DANIELS, B., CRONI, K., BANNERJI, R., and GILBOA, E. (1990). Interleukin-2 gene transfer into tumor cells abrogates tumorigenicity and induces protective immunity. J. Exp. Med. 172, 1217-1224.

GEIGER, J.D., WAGNER, P.D., CAMERON, M.J., SHU, S., and CHANG, A.E. (1993). Generation of T-cells reactive to the poorly immunogenic B16-BL6 melanoma with efficacy in the treatment of spontaneous metastases. J. Immunother. 13, 153-65.

GOLUMBEK, P.T., LAZENBY, A.J., LEVITSKY, H.I., JAFFEE, L.M., KARASUYAMA, H., BAKER, M., and PARDOLL, D.M. (1991). Treatment of established renal cancer by tumor cells engineered to secrete interleukin-4. Science 254, 713-716.

HEADINGTON, J.T. (1993). Dermal dendrocytes. In Dermal Immune System. B.J. Nickoloff, ed. CRC Press, Boca Raton, FL, pp. 8-23.

LEONG, S.P., ENDERS-ZOHR, P., ZHOU, Y.M., STUNTEBECK, S., HABIB, F.A., ALLEN, R.E.J., SAGEBIEL, R.W., GLASSBERG, A.B., LOWENBERG, D.W., and HAYES, F.A. (1999). Recombinant human granulocyte macrophage-colony stimulating factor (rhGM-CSF) and autologous melanoma vaccine mediate tumor regression in patients with metastatic melanoma. J. Immunol. 22, 166-174.

LI, Q., FURMAN, S.A., BRADFORD, C.R., and CHANG, A.E. (1999). Expanded tumor-reactive CD4+ T-cell responses to human cancers induced by secondary anti-CD3/anti-CD28 activation. $\underline{\text { Clin. Cancer }}$ Res. 5, 461-469.

METCALF, D., BEGLEY, C.G., and WILLIAMSON, D.J. (1987). Hemopoietic responses in mice injected with purified recombinant murine GM-CSF. Exp. Hematol. 15, 1-9.
MORTON, D.L., WEN, D.R., WONG, J.H., ECONOMOU, J.S., CAGLE, L.A., STORM, F.K., FOSHAG, L.J., and COCHRAN, A.J. (1992). Technical details of intraoperative lymphatic mapping for early stage melanoma. Arch. Surg. 127, 392-399.

NAGAI, E., OGAWA, T., KIELIAN, T., IKUBO, A., and SUZUKI, T. (1998). Irradiated tumor cells adenovirally engineered to secrete granulocyte/macrophage-colony-stimulating factor establish antitumor immunity and eliminate pre-existing tumors in syngeneic mice. Cancer Immunol. Immunother. 47, 72-80.

NESTLE, F.O., ZHENG, X.G., THOMPSON, C.B., TURKA, L.A., and NICKOLOFF, B.J. (1993). Characterization of dermal dendritic cells obtained from normal human skin reveals phenotypic and functionally distinctive subsets. J. Immunol. 151, 6535-6545.

NESTLE, F.O., BURG, G., FAH, J., and NICKOLOFF, B.J. (1997a). In vivo and in vitro characterization of human tumor associated dendritic cells: Deficiency in $\mathrm{T}$ cell co-stimulatory molecules and impaired antigen-presenting function. Am. J. Pathol. 150, 641-651.

NESTLE, F.O., BURG, G., and NICKOLOFF, B.J. (1997b). Tumor associated dendritic cells possess markedly diminished levels of $\mathrm{T}$ cell co-stimulatory molecules CD80 and CD86. Am. J. Pathol. 150, 641-652.

PEREZ-DIEZ, A., BUTTERFIELD, L.H., LI, L., CHAKRABORTY, N.G., ECONOMOU, J.S., and MUKHERJI, B. (1998). Generation of CD8+ and CD4+ T-cell to dendritic cells genetically engineered to express the MART-1/Melan-A gene. Cancer Res. 58, 5305-5309.

ROSENBERG, S.A., SPIESS, P., and LAFRENIERE, P. (1986). A new approach to the adoptive immunotherapy of cancer with tumor-infiltrating lymphocytes. Science 233, 1318-1321.

SALLUSTO, F., and LANZAVECCHIA, A. (1994). Efficient presentation of soluble antigen by cultured human dendritic cells is maintained by granulocyte/macrophage colony-stimulatin $g$ factor plus interleukin 4 and down regulated by tumor necrosis factor $\alpha$. J. Exp. Med. 179, 1109-1118.

SHU, S.Y., CHOU, T., and SAKAI, K. (1989). Lymphocytes generated by in vivo priming and in vitro sensitization demonstrate therapeutic efficacy against a murine tumor that lacks apparent immunogenicity. J. Immunol. 143, 740-748.

TANIGAWA, K., YU, H., SUN, R., NICKOLOFF, B.J., and CHANG, A.E. (2000). Gene gun application in the generation of effector $T$ cells for adoptive immunotherapy. Cancer Immunol. Immunother. 48, 635-643.

WITMAR-PACK, M.D., OLIVIER, W., VALINSKY, J., SCHULER, G., and STEINMAN, R.M. (1987). Granulocyte/macrophage colonystimulating factor is essential for the viability and function of cultured murine epidermal Langerhans cells. J. Exp. Med. 166, 1484-1498.

YOSHIZAWA, H., CHANG, A.E., and SHU, S. (1991). Specific adoptive immunotherapy mediated by tumor-draining lymph node cells sequentially activated with anti-CD3 and IL-2. J. Immunol. 147, $729-737$.

Address reprint requests to: Dr. Alfred E. Chang 3302 Cancer Center

1500 E. Medical Center Drive Ann Arbor, MI 48109

Received for publication October 11, 1999; accepted after revision January 21, 2000. 


\section{This article has been cited by:}

1. Seagal Teitz-Tennenbaum, Qiao Li, Mary A. Davis, Kari Wilder-Romans, Janet Hoff, Mu Li, Alfred E. Chang. 2009. Radiotherapy Combined With Intratumoral Dendritic Cell Vaccination Enhances the Therapeutic Efficacy of Adoptive T-cell Transfer. Journal of Immunotherapy 32:6, 602-612. [CrossRef]

2. I. Caroline Poole, Wafic M. ElMasri, Cecele J. Denman, Tara M. Kroll, Hemamalini Bommiasamy, Gretchen Lyons Eiben, W. Martin Kast. 2008. Langerhans cells and dendritic cells are cytotoxic towards HPV16 E6 and E7 expressing target cells. Cancer Immunology, Immunotherapy 57:6, 789-797. [CrossRef]

3. H Wang, T C Thompson. 2008. Gene-modified bone marrow cell therapy for prostate cancer. Gene Therapy 15:10, 787-796. [CrossRef]

4. Andrew D. Simmons, Betty Li, Melissa Gonzalez-Edick, Carol Lin, Marina Moskalenko, Thomas Du, Jennifer Creson, Melinda J. VanRoey, Karin Jooss. 2007. GM-CSF-secreting cancer immunotherapies: preclinical analysis of the mechanism of action. Cancer Immunology, Immunotherapy 56:10, 1653-1665. [CrossRef]

5. Adam I Riker, Soroosh Radfar, SuHu Liu, Yixiang Wang, Hung T Khong. 2007. Immunotherapy of melanoma: a critical review of current concepts and future strategies. Expert Opinion on Biological Therapy 7:3, 345-358. [CrossRef]

6. Sophie Dessureault, David Noyes, David Lee, Mary Dunn, William Janssen, Alan Cantor, Eduardo Sotomayor, Jane Messina, Scott J. Antonia. 2007. A phase-I Trial Using a Universal GM-CSF-producing and CD40L-expressing Bystander Cell Line (GM.CD40L) in the Formulation of Autologous Tumor Cell-based Vaccines for Cancer Patients with Stage IV disease. Annals of Surgical Oncology 14:2, 869-884. [CrossRef]

7. H Fakhrai, J C Mantil, L Liu, G L Nicholson, C S Murphy-Satter, J Ruppert, D L Shawler. 2007. Phase I clinical trial of a TGF- $\beta$ antisense-modified tumor cell vaccine in patients with advanced glioma. Cancer Gene Therapy 13:12, 1052-1060. [CrossRef]

8. J Nemunaitis, T Jahan, H Ross, D Sterman, D Richards, B Fox, D Jablons, J Aimi, A Lin, K Hege. 2006. Phase $1 / 2$ trial of autologous tumor mixed with an allogeneic GVAX ${ }^{\circledR}$ vaccine in advanced-stage non-small-cell lung cancer. Cancer Gene Therapy 13:6, 555-562. [CrossRef]

9. P. H. Tan, C. L. H. Chan, C. Chan, A. J. T. George. 2006. The evolving role of gene-based treatment in surgery. British Journal of Surgery 92:12, 1466-1480. [CrossRef]

10. Yuqiao Shen, Neil Senzer, John Nemunaitis. 2005. Individualised cancer therapeutics: dream or reality? Therapeutics construction. Expert Opinion on Biological Therapy 5:11, 1427-1441. [CrossRef]

11. John Nemunaitis. 2005. Vaccines in cancer: GVAXR, a GM-CSF gene vaccine. Expert Review of Vaccines 4:3, 259-274. [CrossRef]

12. Larisa Pereboeva, David T Curiel. 2004. Cellular Vehicles for Cancer Gene Therapy. BioDrugs 18:6, 361-385. [CrossRef]

13. Alfred E. Chang, Qiao Li, Guihua Jiang, Theodoros N. Teknos, Douglas B. Chepeha, Carol R. Bradford. 2003. Generation of vaccine-primed lymphocytes for the treatment of head and neck cancer. Head \& Neck 25:3, 198-209. [CrossRef]

14. Kevin Harrington, Luis Alvarez-Vallina, Marka Crittenden, Michael Gough, Heung Chong, Rosa Maria Diaz, Georges Vassaux , Nicholas Lemoine, Richard Vile . 2002. Cells as Vehicles for Cancer Gene Therapy: The Missing Link Between Targeted Vectors and Systemic Delivery?Cells as Vehicles for Cancer Gene Therapy: The Missing Link Between Targeted Vectors and Systemic Delivery?. Human Gene Therapy 13:11, 1263-1280. [Abstract] [PDF] [PDF Plus] 
15. Punit D. Wadhwa, Steven P. Zielske, Justin C. Roth, Christopher B. Ballas, Janice E. Bowman, Stanton L. Gerson. 2002. CANCER GENE THERAPY: Scientific Basis. Annual Review of Medicine 53:1, 437-452. [CrossRef]

16. Peter Hersey. 2002. Advances in the non-surgical treatment of melanoma. Expert Opinion on Investigational Drugs 11:1, 75-85. [CrossRef]

17. Chong-Kook Kim, Kh. H Haider, Soo-Jeong Lim. 2001. Gene medicine: A new field of molecular medicine. Archives of Pharmacal Research 24:1, 1-15. [CrossRef] 